\title{
PENGARUH KEBIJAKAN DIVIDEN DALAM MEMEDIASI RETURN ON ASSET DAN FIRM SIZE TERHADAP RETURN SAHAM \\ (Studi Pada Perusahaan Yang Tergabung Dalam LQ45 di Bursa Efek Indonesia (BEI) Tahun 2011 - 2014)
}

Riawan

Universitas Muhammadiyah Ponorogo

Email: riawan13awan@gmail.com

\begin{abstract}
This study was conducted to examine the influence of fundamental factors of ROA and firm size on dividend policy. And furthermore the influence of profitability, liquidity and dividend policy to return stock in companies incorporated in the LQ45 listed on the Indonesia Stock Exchange for the period 2011-2014. The sampling technique used in this research is purposive sampling with criteria : (1) It is listed in Indonesia Stock Exchange 2011-2014. (2) It is always seem annual financial statements for the period 2011-2014. (3) It is always pay dividends. The data required in this study were drawn from the Indonesian Capital Market Directory (ICMD) from 2011 to 2014 consisting of 16 companies. Multiple regression analysis of the data. Hypothesis test used the t-statistic at the 5\% significance level. The results showed ROA, firm size and dividend policy have a significant effect on stock returns. These results indicate that the performance of the fundamental factors of profitability, firm size and dividend policy on stock returns are used by investors to predict stock returns companies incorporated in the LQ45 listed in Indonesia Stock Exchange in 2011-2014.
\end{abstract}

Key Words: Stock Return, dividend policy, ROA, firm size

\section{PENDAHULUAN}

Perusahaan dapat dijadikan sebagai pusat kegiatan yang digunakan untuk mengelolah sumber-sumber ekonomi termasuk penyediaan barang dan jasa yang akan dikonsumsi oleh masyarakat setempat dan disisi lain perusahaan akan memperoleh keuntungan dari hasil penjualan barang dan jasa terebut

Sasaran perusahaan dalam menghimpun keuntungan yang sebesarbesarnya adalah untuk memberikan kesejahteraan kepada pihak pemilik perusahaan atau investor yang menginvestasikan hartanya. Seorang investor dalam melakukan investasi 
memiliki harapan besar untuk mendapatkan return yang tinggi dari hasil investasinya. Return merupakan alasan seseorang untuk berinvestasi guna mendapatkan keuntungan.Return saham merupakan kelebihan harga jual saham diatas harga belinya, yang umumnya dinyatakan dalam persentase terhadap harga beli. Return yang di harapkan investor dari investasi yang di lakukannya merupakan kompensasi atas biaya kesempatan (opportunity cost) dan resiko penurunan daya beli akibat adanya inflasi. Semakin tinggi harga jual saham di atas harga belinya, maka semakin tinggi pula return yang diperoleh investor (Ang, 1997).

Investor akan berani melakukan investasi pada perusahaan jika melihat kinerja keuangan perusahaan dalam kondisi menguntungkan atau beresiko. Hal ini dapat di lihat dari aspek keuntungan (Profitabilitas), aspek firm size dan aspek kebijakan dividennya untuk berinvestasi dengan harapan akan mendapatkan tingkat return yang tinggi.

Rasio Profitabilitas merupakan rasio yang menggambarkan kemampuan perusahaan dalam menghasilkan laba dari sumber dana yang dimiliki(Saniman Widodo, 2007). Oleh karena itu, manajemen perusahaan dalam praktiknya dituntut harus mampu untuk memenuhi target yang telah ditetapkan. Artinya besarnya keuntungan haruslah dicapai sesuai dengan yang diharapkan (Kasmir,
2012).Hasil ini sejalan dengan penelitian yang dilakuakan oleh Prihantini, (2009) bahwa profitabilitas (ROA) berpengaruh positif dan signifikan terhadap Return Saham.Namun pada penelitian lain menemukan hasil bahwa profitabilitas tidak berpengaruh signifikan terhadap return saham (Susilowati\&Turyanto, 2011).

Selain profitabilitas dalam memperngaruhi return saham, ukuran perusahaanjuga dapat dijadikan sebagai indikator apakah perusahaan tersebut mampu menghadapi resiko dalam menjalankan usahanya. Ukuran perusahaan adalah cerminan dari besarnya aset atau total aset yang di miliki perusahaan (Bambang R, 1995). Ukuran Perusahaan yang akan mempunyai dampak terhadap minat investor untuk memiliki saham pada perusahaan tersebut sehingga harga saham mengalami peningkatan karena adanya tekanan permintaan dan secara otomatis juga meningkatkan return saham. Hal ini menunjukkan bahwa semakin besar total asset yang di miliki perusahaan akan memberikan signal positif kepada para investor untuk berinvestasi. Dengan peningkatan nilai investasi akan mempengaruhi dividend yang diperoleh investor semakin meningkat.

Kebijakan deviden adalah salah satu kebijakan keuangan yang penting dan dikendalikan langsung oleh perusahaan. Penentuan besarnya Dividend Payout Ratio akan menentukan besar kecilnya laba yang ditahan. Setiap ada penambahan laba yang ditahan berarti ada penambahan modal sendiri dalam perusahaan yang diperoleh dengan biaya murah.Jumlah dividen 
yang akan dibayarkan akan mempengaruhi harga saham atau kesejahteraan para pemegang saham sehingga akan mempengaruhi nilai saham kedepannya. Hal ini dibuktikan dengan penelitian oleh (Ratmin, 2004); menunjukan bahwa dividend payout ratio berpengaruh signifikan terhadap return saham.

Dari beberapa hasil penelitian yang dilakukan oleh peneliti terdahulu terdapat ketidak konsistenan dalam hasil penelitian mengenai pengaruh profitabilitas dan ukuran perusahaan terhadap return saham. Oleh karena itu, peneliti mencoba memediasi pengaruh profitabilitas dan ukuran perusahaan terhadap return saham dengan dividend payout ratio. Saelain research gap yang mendasari penelitian ini, ada beberapa fenomena yang terdapat pada perusahaan yang tergabung dalam LQ45 khususnya pada nilai return saham yang diperoleh dari tahun 20112014. Untuk lebih jelasnya dapat dilihat pada grafik berikut ini:

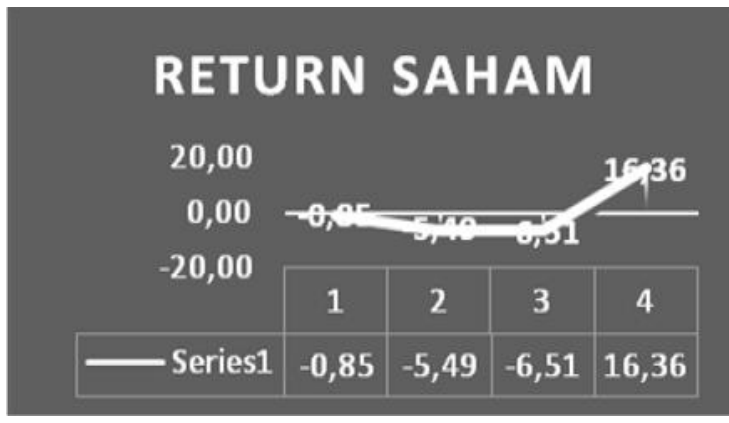

Grafik : 1.1 Perkembangan return saham
Dari grafik di atas menunjukan bahwa nilai return saham yang diperoleh dari tahun 2011-2014 mengalami fluktuasi yaitu dari tahun 2011-2013 mengalami penurunan yang secara beruntun dan pada tahun 20132014 mengalami peningkatan yang signifikan. Dengan terjadinya fluktuasi return saham, tentunya ada faktorfaktor yang mempengaruhi peningkatan dan penurunan nilai return yang diperoleh antara lain adalah profitabilitas, ukuran perusahaan dan kebijakan dividend. Sehingga peneliti akan menggunakan ketiga faktor tersebut yaitu profitabilitas, ukuran perusahaan dan kebijakan dividend untuk menguji seberapa besar pengaruhnnya terhadap return saham.

Berdasarkan uraian research gap dan fenomena gap di atas maka peneliti mengajukan penelitian dengan judul "Pengaruh Profitabilitas dan ukuran perusahaan serta Dividen Payout RatioTerhadap Return Saham pada Perusahaan yang Tergabung dalamLQ45 yang Terdaftar pada Bursa Efek Indonesia (BEI) Periode 2011 - 2014".

Menurut Elton \& Gruber (1995) saham adalah menunjukkan hak kepemilikan pada keuntungan dan aset dari suatu perusahaan. Secara sederhana, saham dapat didefinisikan sebagai surat berharga yang menjadi bukti penyertaan atau kepemilikan individu maupun industri dalam suatu perusahaan.

Menurut Usman (2004) komponen return terdiri dari dua jenis: current income (pendapatan lancar), dan 
Capital Gain (keuntungan selisih harga). Current income merupakan keuntungan yang diperoleh melalui pembayaran yang bersifat periode seperti: pembayaran bunga deposito, bunga obligasi, dividen dan sebagainya. Current income disebut sebagai pendapatan lancar, karena keuntungan yang diterima biasanya dalam bentuk kas, sehingga dapat diuangkan secara cepat, seperti bunga atau jasa giro, dan dividen tunai juga dapat dalam bentuk setara kas seperti bonus atau dividen saham yaitu dividen yang dibayarkan dalam bentuk saham dan dapat dikonversikan menjadi uang kas.

Komponen kedua dari return adalah capital gain, yaitu keuntungan yang diterima karena adnya selisih antara harga jual dengan harga beli saham suatu instrumen investasi. Capital gain sangat bergantung dari harga pasar instrumen investasi, yang berarti bahwa instrumen investasi harus diperdagangkan dipasar. Dengan adanya perdagangan maka akan timbul perubahan nilai suatu instrumen investasi yang memberikan captal gain.

Return atau pengembalian atas kegiatan investasi merupakan penghasilan yang di terima dari suatu investasi di tambah dengan perubahan harga pasar, yang biasanya dinyatakan sebagai persentase dari harga pasar awal dari investasi tersebut (James \& Jhon, 2009).Return merupakan hasil yang diperoleh dari investasi. Return dapat berupa return realisasi yang sudah terjadi atau return ekspektasi yang belum terjadi tetapi yang diharapkan di masa mendatang. Return realisasi (realized return) merupakan return yang telah terjadi, dihitung berdasarkan data historis. Return realisasi penting karena digunakan sebagai salah satu pengukur kinerja dari perusahaan (Ang, 1997).

Pengembangan hipotesis yang dikembangkan dalam penelitian ini adalah sebagai berikut;

1) Terdapat pengaruh yang signifikan antara kebijakan dividen terhadap return saham.

2) Terdapat pengaruh yang signifikan antara Profitabilitas terhadap return saham.

3) Terdapat pengaruh yang signifikan antara Profitabilitas terhadap kebijakan dividen

4) Terdapat pengaruh yang signifikan antara ukuranperusahaanterhadap return saham.

5) Terdapat pengaruh yang signifikan antara ukuranperusahaan terhadap kebijakan dividen.

\section{METODE PENELITIAN}

\section{Sampel Penelitian}

Dalam penelitian ini populasi yang digunakan adalah perusahaan yang tergabung dalam LQ45 yang go-public di BEI tahun 2011 - 2014. Pengambilan sampel dalam penelitian ini dilakukan dengan menggunakan metode purposive sampling. Dengan jumlah sampel yang memenuhi kriteria adalah 16 perusahaan. 


\section{Tehnik Analisis}

Analisis estimasi data dari seluruh model persamaan regresi dalam penelitian ini dilakukan dengan bantuan Program IBM SPSS 20. Teknik analisis yang digunakan dalam penelitian ini adalah analisis regresi berganda dengan persamaan regresi adalah :

$Y_{1}=a+b_{1} x_{1}+b_{2} x_{2}+e_{1}$

dan

$Y_{2}=a+b_{1} x_{1}+b_{2} x_{2}+b_{3} Y_{1}+e_{2}$

Keterangan :

a $=$ intercept

$b_{1}, b_{2}, b_{3}=$ koefisien regresi

$\mathrm{Y}_{1}=$ Kebijaka Dividen

$\mathrm{x}_{1}=$ Profibalitas $(\mathrm{ROA})$

$\mathrm{Y}_{2}=$ Return Saham

$\mathrm{x}_{2}=$ Firm size

$\mathrm{e}_{1}=$ error $/$ residual persamaan 1

$\mathrm{e}_{2}=$ error $/$ residual persamaan 2

\section{Uji Hipotesis}

Dalam penelitian ini untuk pengujian hipotesis menggunakan Uji t. Uji $t$ adalah uji parsial yang digunakan untuk menguji keterkaitan antara variabel bebas secara individual dengan variabel terikat.

\section{Uji Asumsi Klasik}

Untuk mendapatkan model regresi yang tidak bias maka perlu dilakukan uji asumsi klasik meliputi ; uji multikolinearitas, autokorelasi dan heterokedastisitas

\section{HASIL ANALISIS \\ Analisis Regresi}

Untuk mengetahui ada tidaknya pengaruh variabel bebas (independen) terhadap variabel terikat (dependen) di dalam penelitian ini,maka dilakukan analisis regresi linear berganda. Analisis regrsi linear berganda dalam penelitian ini dilakukan dengan menggunakan bantuan program SPSS versi 20. Berdasarkan hasil pengolahan data maka di ketahui hasil untuk analisis regresi linear berganda untuk kebijakan dividen (Y1) disajikan pada tabel di bawah ini:

Tabel 4.8 Hasil Perhitungan Regresi Linear Berganda

Coefficients

Variabel Dividend Payout (Y1)

$\begin{array}{lll}\text { a } & \text { Unstandardized Coefficients } & \begin{array}{c}\text { Standardized } \\ \text { Coefficients }\end{array}\end{array}$

\begin{tabular}{|c|c|c|c|c|c|c|}
\hline & & B & Std. Error & Beta & & \\
\hline \multirow{3}{*}{1} & (Constant) & 102.408 & 30.609 & & 3.346 & .001 \\
\hline & $\mathrm{X} 1$ & .771 & .194 & .482 & 3.968 & .000 \\
\hline & $\mathrm{X} 2$ & 8.619 & 3.724 & .281 & -2.314 & .024 \\
\hline
\end{tabular}

JURNAL AKUNTANSI DAN PAJAK, VOL. 17, NO. 02, JANUARI 2017 - 40 
Dari tabel diatas, hasil pengujian model regresi terhadap variabel independent, menunjukan bahwa variabel ROA berpengaruh signifikan yaitu lebih kecil dari 0,05. Dan variabel ukuran perusahaan berpengaruh siginifikan yaitu lebih kecil 0,05. Dari hasil tersebut Kebijakan dividen dipengaruhi oleh ROA dengan persamaan regresi sebagai berikut:Dividend Payout $=102,408+$ 0,771 ROA - 8,619 Size

Dari model persamaan regresi linear berganda tersebut selanjutnya dapat di jelaskan sebagai berikut:

1. Konstanta sebesar 102,408 menyatakan bahwa jika variabel independen dianggap konstan, maka rata-rata rasio nilai dividend yang dibayarkan sebesar sebesar $102,408 \%$.
2. Koefisien regresi dari ROAadalah sebesar 0,771. Nilai koefisien positif menunjukkan bahwa profitabilitas berpengaruh positif terhadap DPR. Artinya bahwa jika ROAmeningkat 1\% maka akan meningkatkan DPR sebesar $0,771 \%$

3. Koefisien regresi dari ukuran perusahaanadalah sebesar 8.619. Nilai koefisien positif menunjukkan bahwa profitabilitas berpengaruh positif terhadap DPR. Artinya bahwa jika ukuran perusahaan meningkat $1 \%$ maka akan meningkatkan DPRsebesar 8.619\%

Berikut ini adalah pengujian $\mathrm{Y}_{2}$ dengan menggunakan perhitungan analisis linear berganda untuk variabel returnsaham. Sehingga diperoleh hasil yang disajikan pada tabel beikut :

Tabel 4.9 Hasil Perhitungan Regresi Linear Berganda

Variabel Return Saham (Y2)

\begin{tabular}{l} 
Coefficients \\
\hline Model \\
\hline \\
\hline 1 \\
\\
\hline a. \\
Dependent \\
Variable: Y2
\end{tabular}

Tabel di atas menguji variabel independen yang diuji kedalam model regresi, menunjukan bahwa variabel profitabilitas (ROA), dan dividend payout signifikan terhadap nilai perusahaan dengan probabilitas signifikansi pada 
0,05. Berdasarkan hasil tersebut disimpulkan bahwa return saham dipengaruhi oleh profitabilitas (ROA), dan dividend payout (DPR) dengan persamaan matematis :

Return Saham $=70.421+0.817 \mathrm{ROA}+$ 9,722size + 0.312 DPR

1. Konstanta sebesar 70.421 menyatakan bahwa jika variabel independen dianggap konstan, maka rata-rata rasio nilai dividend yang dibayarkan sebesar sebesar $70.421 \%$.

2. Koefisien regresi dari ROA adalah sebesar 0.817. Nilai koefisien positif menunjukkan bahwa profitabilitas berpengaruh positif terhadap return saham. +Artinya bahwa jika ROAmeningkat $1 \%$ maka akan meningkatkan DPRsebesar 0.817\%

3. Koefisien regresi dari Kebijakan dividen adalah sebesar 9,722. Nilai koefisien positif menunjukkan bahwa dividen berpengaruh positif terhadap return saham. Artinya bahwa jika dividenmeningkat $1 \%$ maka akan meningkatkan return saham sebesar $9,722 \%$

\section{PEMBAHASAN}

a. Pengaruh Profitabilitas terhadap dividend payout

Berdasarkan hasil penelitian dan pengujian hipotesis diperoleh bahwa profitabilitas berpengaruh positif dan signifikan terhadap dividend payout pada perusahaan yang tergabung dalam LQ45 yang terdaftar di Bursa Efek Indonesia periode 2011- 2014. Hasil penelitian ini sesuai dengan apa yang di kemukakan oleh Hanafi (2004) dalam (Puspita 2009) bahwa perusahaan yang mempunyai aliran kas atau profitabilitas yang tinggi diharapakan bisa membayar deviden atau meningkatkan deviden. Dengan tingginya laba yang diperoleh perusahaan tersebut akan semakin tinggi pula ketersediaan kas dalam perusahaan sehingga diharapkan perusahaan akan membayar dividen yang tinggi kepada para pemegang saham. disisi lain dengan profitabilitas yang tinggi yang diperoleh suatu perusahaan, akan menarik minat investor untuk berinvestasi diperusahaan tersebut dengan harapan mendapatkan keuntungan yang lebih besar dari dividen yang mereka peroleh.

Hasil penelitian ini sejalan dengan penelitian yang dilakukan oleh Chasanah N. (2008), Hoei Devi S., (2013)dimana return on asset berpengaruh posistif dan signifikan terhadap dividen payout.

b. Pengaruh Size Firm terhadap Kebijakan Dividen

Berdasarkan hasil penelitian dan pengujian hipotesis diperoleh hasil bahwa size firmberpengaruh positif dan signifikan terhadap dividend payoutpada perusahaan yang tergabung dalamLQ45 yang terdaftar di Bursa Efek Indonesia (BEI) periode 2011 - 2014. Hal ini 
menunjukkan bahwa size firmyang perusahaan yang besar akan mempengaruhi pembagian dividen kepada pemegang saham. Perusahaan dengan ukuran yang besar cenderung memiliki suatu kemudahan dalam aksesnya menuju pasar modal. Tentu saja hal tersebut mempengaruhi fleksibilitas perusahaan besar tersebut dalam memperoleh dana dalam jumlah besar. Perolehan dana tersebut, dapat digunakan sebagai pembayaran dividen bagi pemegang sahamnya. Semakin besar tingkat ukuran suatu perusahaan, kemungkinan tingkat pembayaran dividen akan semakin besar pula. hal ini sejalan dengan penelitian yang dilakukan oleh Imran (2011) dan Huang et al. (2012) bahwa ukuran perusahaan dapat mempengaruhi dividen yang akan diperoleh para pemilik modal.

\section{Pengaruh Profitabilitas (ROA), Firm} Size dan Kebijakan Dividen terhadap Return Saham

\section{a. Pengaruh provitabilitas (ROA) terhadap return saham}

Berdasarkan hasil penelitian dan pengujian hipotesis diperoleh hasil bahwa profitabilitas (ROA) berpengaruh positif dan signifikan terhadap Return Saham pada perusahaan yang tergabung dalam LQ45 yang terdaftar di Bursa Efek Indonesi periode 2011 - 2014. Hal ini menunjukan bahwa perusahaan yang memiliki laba yang tinggi dengan prospek kinerja perusahaan yang baik maka para pemegang saham akan menerima dividen semakin tinggi. Dividen yang semakin tinggi akan menjadi sebuah informasi kepada para investor-investor lain untuk menanamkan modalnya di perusahaan tersebut dengan tujuan untuk memperoleh keuntungan yang lebih besar. Dengan banyaknya investor untuk berinvestasi di perusahaan tersebut maka akan terjadi perubahan volume dari perdagangan saham. Apabila jumlah permintaan saham meningkat maka akan memicu naiknya harga saham, sehingga para investor akan memperoleh return yang tinggi dari modal yang diinvestasikan.Hasil penelitian ini sejalan dengan penelitian yang dilakukan oleh Ayu Dika P., Gede Mertha S. (2016)dan Ni Luh Lina, Mariani, (2016) mengemukakan bahwa ROA berpengaruh signifikan terhadap return saham

Hasil penelitian ini dapat digunakan sebagai informasi bagi para pemilik saham perusahaan bahwa dengan prosentase profitabilitas yang tinggi akan meningkatkan return saham perusahaan.

\section{b. Size Firm terhadap Return saham}

Berdasarkan hasil penelitian dan pengujian hipotesis diperoleh hasil bahwa tidak terdapat hubungan signifikan antara size firmterhadap return saham pada perusahaan yang tergabung dalam LQ45 yang terdaftar di 
Bursa Efek Indonesia (BEI) periode 2011 -2014. Hal ini menunjukkan bahwa size firm belum mampu menjelaskan pengaruhnya terhadap return saham. size firm tercermin pada besaernya total asset yang dimiliki oleh perusahaan, namun pada penelitian ini pada penelitian ini total aset belum mampu memberikan signal positif kepada para investor untuk berinvestasi dengan melakukan pembelian saham. Hal ini sejalan penelitian yang dilakukan oleh Agus Zulbay (2014) bahwa size firm tidak memiliki pengaruh yang signifikan terhadap return saham

Hasil penelitian ini dapat memberikan informasi bahwa size firm tidak mempengaruhi return saham perusahaan. sehingga persentase size firm suatu perusahaan dalam penelitian ini tidak menjadi prioritas dalam memilih investasi yang mengharapkan return.

\section{c. Pengaruh kebijakan dividen terhadap Return saham}

Berdasarkan hasil penelitian, diketahui bahwa dividend berpengaruh positif signifikan terhadap nilai perusahaan. Artinya bahwa dividend yang tinggi akan meningkatkan return saham. Hal ini disebabkan oleh informasi yang diberikan dari pembagian dividend tersebut bahwa perusahaan sedang dalam kondisi baik dan mampu membagikan dividendnya kepada pemegang saham perusahaan. Dengan demikian para investor akan menerima saham yang tinggi dari investasi yang diberikan.Hal ini sejalan dengan penelitian yang dilakukan oleh (Jauhari B. 2003) bahwa pembayaran dividen dapat memberikan sinyal positif terhadap return saham.

Hasil penelitian ini memberikan informasi bahwa dividend payout memberikan pengaruh terhadap return saham. hal ini disebabkan oleh signal positif yang ditimbulkan oleh pembayaran dividend tersebut, dimana perusahaan yang membayarkan dividend berarti sedang memiliki cash flow yang cukup untuk membiayai kegiatan operasionalnya dan membayarkan dividend kepada pemegang saham perusahaan tersebut. Sehingga persentase dividend suatu perusahaan dapat meningkatkan return saham.

\section{KESIMPULAN DAN SARAN Kesimpulan}

Return ono asset berpengaruh positif dan signifikan terhadap return saham. Hasil ini menunjukkan bahwa semakin tinggi ROA yang dicapai oleh perusahaan maka return saham semakin tinggi yang diperoleh pemegang saham. Firm size berpengaruh tidak signifikan terhadap return saham. Hasil ini menunjukan bahwa firm size tidak dapat mempengaruhi return saham

Kebijakan dividen berpengaruh positif dan signifikan terhadap return saham. Hasil ini menunjukan bahwa hasil ini menunjukan bahwa pembayaran dividen yang tinggi akan memberikan informasi penting mengenai kondisi 
perusahaan sehingga dapat mempengaruhi return saham yang akan diterima oleh para investor.

Profitabilitas berpengaruh positif dan signifikan terhadap kebijakan dividen. Hasil penelitian ini menunjukkan bahwa semakin tinggi profitabilitas maka dividen yang akan di bagi kepada pemilik modal semakin tinggi pula.

Firm size berpengaruh signifikan terhadap kebijakan dividen. Hasil ini menunjukkan bahwa firm size memberikan pengaruh terhadap besarnya dividen yang akan dibagikan terhadap para pemilik modal.

\section{Saran}

Bagi manajer keuangan, karena faktor fundamental yang tersaji dari laporan keuangan sangat diperlukan oleh para investor, sehingga dapat digunakan sebagai sinyal positif untuk menilai return saham.

Hasil penelitian ini dapat dipergunakan sebagai bahan informasi bagi perusahaan bahwa dalam meningkatkan tingkat keuntungan atau return saham harus menfokuskan perhatian mereka pada firm size, return on asset dan dividend payout karena dengan profitabilitas dan dividend yang tinggi dapat meningkatkan return saham perusahaan.

Selanjutnya return on asset dapat dijadikan sebagai acuan dalam menentukan strategi investasi para investor dalam menanamkan modalnya dipasar modal. Hal ini dikarenakan profitabilitas yang meningkat menunjukkan kinerja perusahaan yang semakin baik dan para pemegang saham akan memperoleh dividen yang akan diterima semakin meningkat.

\section{DAFTAR PUSTAKA}

\section{Buku}

Ang, Robert., 1997, "Buku Pintar Pasar Modal Indonesia," Edisi Pertama, Rineka Cipta, Jakarta

Bambang Riyanto. 1995. DasarDasarPembelanjaan Perusahaan. Yogyakarta: Yayasan Badan Penerbit Gadjah Mada

James C. Horne \& John M. Wachowich, Jr. 2009. Fundamentals Of Financial Managemen. Jakarta : Salemba Empat.

Kasmir, 2012. Analisis Laporan Keuangan. PT. RajaGrafindo Persada, Jakarta

\section{Artikel dalam Jurnal}

Ayu Dika P., Gede Mertha S. (2016). Pengaruh Profitabilitas, Leverage, Likuiditas Dan Penilaian Pasar Terhadap Return Saham Pada Perusahaan Manufaktur.E-Jurnal Manajemen Unud, Vol. 5, No.1, 2016: 385 - 413. ISSN: 2302-8912 
Elton, Edwin J., Gruber \& Cristopher R. Blake, 1995, "Fundamental Economic Variables, Expected Return and Bond Fund Performance", Journal of Finance, Vol 1, No. 4, September

Hoei Devi S., 2013. Pengaruh Kebijakan Utang, Profitabilitas dan Likuiditas terhadap Kebijakan Dividen dengan Size sebagai Variabel Moderasi pada Sektor Manufaktur Periode 20082011. Jurnal Ilmiah Mahasiswa Universitas Surabaya. Vol 2. No 1. 2013

Huang, Yuting; Chen Anlin; Kao Lanfeng. 2012. Corporate governance in Taiwan: The nonmonotonic relationship between family ownership and dividend policy. Asia Pac J Manag. 29: h: 39-58

Imran, Kashif. 2011. Determinants Of Dividend Policy: A Case Of Engineering Sektor. The Romanian Economic Journal. 14(41): h: 47-60.

Ni Luh Lina, Mariani, (2016), Pengaruh Profitabilitas Dan Leverage Terhadap Return Saham. e-Journal Bisma Universitas Pendidikan Ganesha Jurusan Manajemen (Volume 4 Tahun 2016).

Susilowati \& Turyanto, 2011. Profit abilityandsolvability ratio reaction signal toward stock return company. Dinamika Keuangan dan
Perbankan. Vol. 3 No. 1 Mei 2011. Hal. 17 - 37. ISSN 1979-4878

Karya Tidak Terpublikasikan

Agus Zulbay (2014). Peran Struktur Modal Dalam Memediasi Pengaruh Profitabilitas Dan Ukuran Perusahaan Terhadap Return Saham Pada Perusahaan Manufaktur Yang Terdaftar Di Bursa Efek Indonesia (Bei) Tahun 2010 - 2012. Thesis. Magister Manajemen UNISSULA.

Chasanah N. 2008. Faktor-faktor yang mempengaruhi Dividend Payout Ratio (DPR) pada Perusahaan yang listed di bursa efek Indonesia. Tesis. Magister Manajemen. Universitas Diponegoro. Semarang.

Jauhari B., 2003. Analisis Pengaruh DebtToEquity Ratio, Price To Book Vakue, Return On Aquity, Price To Earning Ratio dan Devidend Payout Ratio terhadap Return Saham : Studi Kasus pada Saham LQ45 di Bursa Efek Jakarta. Tesis. Universitas Diponegoro. Semarang.

Prihantini, 2009. Analisis Pengaruh Inflasi, Nilai Tukar, ROA, DER dan CR terhadap Return Saham (studi kasus saham industri real estate and property yang terdaftar di bursa Efek Indonesia periode 2003 - 2006). Tesis. Universitas Diponegoro. Semarang. 
Pengaruh Kebijakan Dividen Dalam Memediasi

Return On Asset Dan Firm Size Terhadap Return Saham

ISSN : 1412-629X

Puspita, 2009. Analisis faktor-faktor yang mempengaruhi kebijakanDividend payout ratio ; Studi Kasus Pada Perusahaan Yang Terdaftar Di Bursa Efek Indonesia Periode 2005-2007). Tesis. Magister Manajemen. Universitas Diponegoro. Semarang

Ratmin, 2004. Pengaruh Debt To Equity Ratio, Price To Earning Ratio, Net Profit Margin, dan Dividend Payout Ratio terhadap Return Saham. Tesis. Magister Manajemen. Universitas Diponegoro. Semarang

Usman dan Yulianty, 2004, "Analisis Pengaruh EVA, MVA, dan Kinerja Keuangan Konvensional terhadap Return Saham di Bursa Efek Jakarta", Tesis Magister Manajemen Undip, Semarang.

Widodo S., 2007. Analisis pengaruh rasio aktivitas, Rasio Profitabilitas, dan Rasio Pasar, Terhadap Return Saham Syariah dalam Kelompok Jakarta Islamic Index (jii) Tahun 2003 - 2005. Tesis. Universitas Diponegoro. Semarang. 